\title{
MEDAL REVIEW
}

\section{Grafting mouse brains: from neurocarcinogenesis to neurodegeneration}

\author{
Adriano Aguzzi \\ Institute of Neuropathology, University Hospital of Zurich, Department \\ of Pathology, Schmelzbergstrasse 12, CH-8091 Zurich, Switzerland
}

\section{Introduction}

When I received a telephone call in early July 1998 breaking the news that I was to be awarded the EMBO gold medal, I could not help but remember the awe with which I had been looking upon my then-supervisor Erwin Wagner a decade ago, when he was awarded the very same prize. Since I was asked to write an autobiographical review of my scientific activities, I dug out the medal review by Erwin Wagner (1990) in an attempt to gather some inspiration. The latter document is remarkable in its scientific clarity, but also in its candor, typical of Erwin's personality. Along lines similar to those of Erwin Wagner's review article, I will try to trace my scientific motives and achievements, and also describe the impact of the scientists who taught me how to research the molecular bases of diseases.

In 1979, the Italian undergraduate curriculum in the medical sciences was utterly uninviting. Therefore, although my home town of Pavia sports a distinguished university, after no more than one semester I gave up my enrollment at the medical faculty and decided to continue my studies in Germany. Three years into medical school in Freiburg im Breisgau, I felt the urge to learn the methods of basic science. Thanks to the mediation of an old friend, Gianpaolo Merlini (then a postdoc in New York), I was given the opportunity to undertake an elective in Soldano Ferrone's laboratory at Columbia University, where Patrizio Giacomini taught me how to make monoclonal antibodies, and introduced me to the thenomnipresent methods of immunochemistry: sandwich assays, radioimmunoprecipitation, immunofluorescence and so on.

In 1983, as naïve as this may seem with hindsight, immunotherapy of cancer seemed to lie just around the corner. A wealth of tumor antigens was being discovered, and the booming technology of monoclonal antibodies made it seem likely that one could soon use them as magic bullets against cancer (Natali et al., 1983). Several of the genes encoding interferons had been cloned (Nagata et al., 1980; Gray et al., 1982), and since these substances seemed to hold some promise in the therapy of malignant melanoma, Patrizio and I deemed it reasonable to investigate the effects of interferons on the expression of melanoma-associated tumor antigens (Giacomini et al., 1984, 1985b) and of histocompatibility antigens (Giacomini et al., 1985a, 1986). At that time I would not have imagined that, some 10 years later, I was to make the acquaintance of some of the most prominent scientists in the interferon field: Jean Lindenmann who discovered interferon (Isaacs and Lindenmann, 1957) and Charles Weissmann who cloned the first interferon gene (Nagata et al., 1980), and to initiate an extraordinarily fruitful scientific collaboration with the latter, albeit in an area which, to the best of our knowledge, is totally unrelated to interferons.

As we all now know, tumor immunotherapy, with or without interferons, in the years to come did not live up to its early promise. While the last word may not yet have been written on that subject, by the end of my medical training I decided that I had had enough of tumor immunology and opted for moving upwards, i.e. into the central nervous system. In July 1986 I took on a residency in neuropathology with Paul Kleihues, then Director of the Institute of Neuropathology at the University of Zurich.

Ever since the time of Alois Alzheimer, neuropathology has been an exciting field, at the interface between clinical medicine and basic science. When compared with our colleagues in general histopathology, we neuropathologists are a privileged lot: we do not need to spend much of our time diagnosing warts and inflamed gall bladders under the microscope. Also, since surgeons are in general more inclined to remove gall bladders than brains, the total diagnostic workload of neuropathologists is often less than that of general pathologists. Such privileges, however, also bear duties, and therefore one should insist that respectable neuropathologists in academic institutions be engaged in scientific activities, and whose excellence should be measured by the same standards as our colleagues in the natural sciences.

\section{Zurich, part I: brains of humans and mice}

The bread-and-butter of neuropathology is the diagnosis of neuroectodermal tumors resected by neurosurgeons and neurodegenerative diseases, the latter being, for obvious reasons, mainly a post mortem exercise. I found both of these fields exciting enough to dedicate the next 12 years of my scientific career to them. Besides being an eminent morphologist, and the driving force behind the current World Health Organization classification of brain tumors, Paul Kleihues was obsessed with the problem of carcinogenesis in the nervous system, and by the events driving progression of benign gliomas to states of higher malignancy. I was assigned the project of investigating whether expression of tyrosine kinase oncogenes of the $\operatorname{src}$ family might initiate glioma tumorigenesis in mice.

Since the activity of c-src is tightly regulated by tyrosine phosphorylation of the SRC protein (Cooper et al., 1986; Thomas et al., 1991), I feared that overexpression of c-src in transgenic mice might not be helpful in reaching the above goal, and thought it more promising to use constitutively active SRC variants. Unavoidably, I came across the work of Erwin Wagner who had pioneered the 


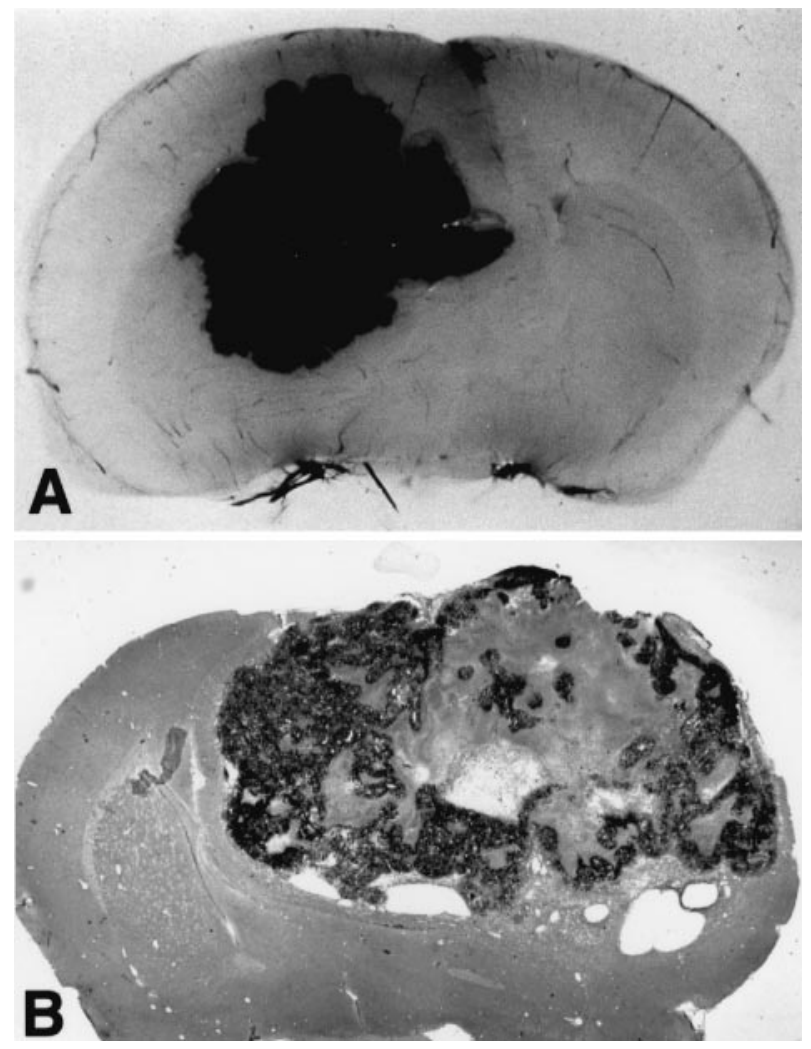

Fig. 1. (A) Endothelial hemangiomas induced in neural grafts by $\mathrm{mT}$ antigen. Frontal hemispheric section through the brain showing a large multichambered hemangioma and multiple hemorrhages in the graft. The vessels have been visualized by perfusion with indian ink-gelatin. (B) A large glioblastoma-like brain tumor, originating from a v-src expressing graft and destroying the surrounding brain tissue. High levels of $\mathrm{v}$-src mRNA are detected by radioactive in situ hybridization: dark areas correspond to high density of silver grains. While viable tumor cells uniformly express high levels of v-src, unlabeled areas within the tumor represent necrotic tissue.

field of in vivo analysis of oncogenes with transgenic mice. A few days later I drove to Heidelberg (with Otmar Wiestler and Roy Weller, a British neuropathologist on sabbatical in Zurich) to meet Erwin at EMBL and to discuss a possible collaboration. I thought it might be interesting to express the viral $\mathrm{v}$-src oncogene or the middle-T antigen of polyoma virus, which binds and activates SRC along with several other enzymes (Courtneidge and Smith, 1983), in astrocytes of mice. However, I soon learnt from Lindsay Williams and Catherine Boulter that constitutive expression of either gene would kill mice during embryogenesis (Williams et al., 1989; Boulter et al., 1991). Consequently, generation of transgenic or chimeric mice with any of the systems available at that time might not prove useful in investigating whether these proteins were tumorigenic for neural tissue, and which kind of tumors they would induce. We therefore transduced primary embryonic neuroectodermal cells of rats with $\mathrm{v}-s r c$, middle $\mathrm{T}$ and $\mathrm{c}-s r^{527 \mathrm{Tyr} \rightarrow \mathrm{Phe}}$ using replication-defective retroviral vectors, and resorted to neural transplantation into wild-type hosts to analyze the consequences. While middle $\mathrm{T}$ induced cavernous hemangiomas in the brains of recipient animals, v-src led to the development of astrocytomas (Aguzzi et al., 1991) (Figure 1), yet when middle $\mathrm{T}$ was introduced into the germ line of mice using a very similar construct, neuroblastomas developed (Aguzzi et al., 1990). Several years later, I (with the help of my co-workers Gerhard Malin, Jakob Weissenberger and Joachim Steinbach) ended up hooking v-src to the glial fibrillary acidic protein (GFAP) promoter, and producing what still seems to be the only available transgenic model for astrocytoma development (Weissenberger et al., 1997). Only few GFAP-V-src transgenic mice develop full-blown astrocytomas, but all display preneoplastic lesions: this renders them potentially useful in identifying the genetic lesions responsible for progression of gliomas to malignancy. We are currently pursuing the latter idea using proviral tagging and grafting of GFAP-V-src neuroectodermal tissue (T.Afanasieva, T.Voigtländer, M.G.D'Angelo and A.Aguzzi, unpublished material), an approach similar to the classic studies of Anton Berns on lymphoma development in mice infected with Moloney murine leukemia virus (Jonkers and Berns, 1996).

\section{The Vienna experience}

The application of in vivo gene transfer methodologies to neuropathological questions fascinated me. Therefore it seemed logical to join Erwin Wagner, who had just been appointed to the Institute of Molecular Pathology in Vienna. With Erwin's and Max Birnstiel's generous support, I had the opportunity to set up a tiny unit of 'molecular morphology' (dealing with techniques such as in situ hybridizations) and to analyze genotype-phenotype correlations in a variety of transgenic models of disease (Wagner and Aguzzi, 1992; Hilberg et al., 1993; Thomas et al., 1993; Kiefer et al., 1994; Magyar et al., 1994). It was Ivan Horak and my former brother-in-study Axel Rethwilm who sparked my interest in transgenic models of neurodegenerative diseases, and together with them I spent the next several years attempting to understand the neural damage occurring in transgenic mice expressing genes of the human foamy virus (HFV), a relatively obscure retrovirus which had been claimed to be prevalent in certain regions of Africa. The detailed analysis of HFV transgenic mice led to the identification of viral genes responsible for the various aspects of their complex neurodegenerative phenotype (Bothe et al., 1991; Aguzzi et al., 1992a,b, 1993; Aguzzi, 1993; Netzer et al., 1993; Marino et al., 1995; Tschopp et al., 1996; Lampe et al., 1998). Even now, the system has not lost any of its fascination; since HFV is extremely promiscuous in its choice of host cells, there is some hope that the elimination of the determinants of neurotoxicity may lead to its exploitation as a versatile vector for gene therapy (Bieniasz et al., 1997; Schmidt et al., 1997).

After three years of intimacy with transgenic mice, I desperately wanted to move back into clinical neuropathology. I therefore returned to Zurich, and took up a position as registrar in neuropathology in July 1992. A few months before my departure from Vienna, Erwin had taken me along to a meeting of the Schering Foundation in Berlin on 'transgenic models of disease', and it was there that I had the occasion to spend a memorable evening with Charles Weissmann. By then, Weissmann had been working on prion diseases for almost a decade, and his achievements in this field were instrumental in shifting prion research from rather esoteric grounds to the domain 
Table I. Definitions of prion-related terms

\begin{tabular}{|c|c|}
\hline Term & Definition \\
\hline Prion & $\begin{array}{l}\text { Agent of transmissible spongiform encephalopathy (TSE), with unconventional properties. The term does not have } \\
\text { structural implications other than that a protein is an essential component. }\end{array}$ \\
\hline 'Protein-only' hypothesis & $\begin{array}{l}\text { Maintains that the prion is devoid of informational nucleic acid and consists of protein (or glycoprotein) as its } \\
\text { essential pathogenic component. Genetic evidence strongly suggests that the protein is an abnormal form of PrP. } \\
\text { The association with other 'non-informational' molecules (e.g. lipids or glycosamino glycans) is not excluded. }\end{array}$ \\
\hline $\mathrm{PrP}^{\mathrm{C}}$ or PrP-sen & $\begin{array}{l}\text { The naturally occurring form of the mature Prnp gene product. It is glycosylated, anchored to the plasma membrane } \\
\text { by a GPI residue and poor in } \beta \text {-sheet structure. Its presence in a given cell type is necessary but not sufficient for } \\
\text { the replication of the prion. }\end{array}$ \\
\hline $\mathrm{PrP}^{\mathrm{Sc}}$ or PrP-res & $\begin{array}{l}\text { An 'abnormal' form of the mature Prnp gene product found in tissue of TSE sufferers, operationally defined as } \\
\text { being partly resistant to proteinase } \mathrm{K} \text { digestion under defined reaction conditions. It is believed to differ from PrPC } \\
\text { only (or mainly) conformationally and is rich in } \beta \text {-sheet structure. Within the framework of the 'protein-only' } \\
\text { hypothesis it is often considered to be the transmissible agent or prion. }\end{array}$ \\
\hline Prnp & $\begin{array}{l}\text { The cellular gene encoding the } \mathrm{PrP}^{\mathrm{C}} \text { protein. In addition to Prnp }{ }^{o / o} \text { mice, the most relevant transgenic mice used in } \\
\text { the studies described here include } \operatorname{tga} 20 \text { mice which express a 'half-genomic' Prnp transgene and are hypersensitive } \\
\text { to scrapie (Fischer } \text { et al., 1996), and tg } 33 \text { mice which express PrP under control of the T lymphocyte-specific lck } \\
\text { promoter (A.J.Raeber, A.Sailer, T.Rülicke, S.Brandner, M.Klein, M.Fischer, A.Aguzzi and C.Weissmann, } \\
\text { unpublished data). }\end{array}$ \\
\hline
\end{tabular}

These definitions describe the terminology used in Zurich, which is not agreed on by convention and is therefore not necessarily used by others.

of solid molecular biology. Amongst other things, Charles had isolated Prnp (Table I), the gene which encodes the normal prion protein $\operatorname{PrP}^{\mathrm{C}}$, thereby providing crucial evidence in favor of Stan Prusiner's 'protein-only' hypothesis of prion replication, and suggesting the possibility that infectious prions might replicate by recruitment and conversion of normal prion protein (Oesch et al., 1985, 1988; Basler et al., 1986). He had also produced a remarkable amount of theoretical work on the protein-only theory (Weissmann, 1989, 1991a,b). With his colleagues Michel Aguet and Hansrüedi Büeler, Charles had gone on to create Prnp knockout mice (Büeler et al., 1992).

\section{Zurich, part II: tracking prions}

Charles Weissmann was not entirely happy with the histopathological analysis of these mice, and when he learnt that I intended to move to Zurich he immediately proposed that we collaborate on the attempt of infecting Prnpolo mice with a mouse-adapted strain of the sheep scrapie agent. Sure enough, knockout mice stayed healthy and displayed no neuropathological changes in their brains (Büeler et al., 1993); moreover, they did not support replication of the infectious agent (Sailer et al., 1994). My involvement in these now-famous studies was essentially restricted to histopathological analyses: it is typical of Charles Weissmann's generosity that he let me participate in this project, and also in fact in all other prion-related experiments in his laboratory. Ever since, Weissmann unconditionally and enthusiastically supported my wish to establish my own prion research program.

My initial desire was to elucidate the pathogenetic events which are initiated by the introduction of prions into the brain, and which eventually result in the tremendous cerebral damage typical of patients who develop Creutzfeldt-Jakob disease. Almost nothing was known about the molecular basis of this process. In theory, CNS damage could occur because of $\mathrm{PrP}^{\mathrm{Sc}}$ toxicity, or because the conversion of $\mathrm{PrP}^{\mathrm{C}}$ into $\mathrm{PrP}^{\mathrm{Sc}}$ may abruptly reduce its availability to cellular processes for which it may be needed. The fact that Prnp knockout mice do not suffer from spontaneous scrapie does not necessarily rule out the second hypothesis, since absence of $\mathrm{PrP}^{\mathrm{C}}$ from early development may arguably be compensated for more easily than withdrawal during adult life.

By then, we had learnt much about the biology of neural grafts (Isenmann et al., 1995, 1996a,b), and I had convinced myself that the neurografting technology could be useful for addressing a variety of questions, not necessarily related to carcinogenesis. Therefore, it was only logical to try to figure out whether neurografting could represent a possible approach to the question of prion neurotoxicity. My original idea was that a piece of brain highly overexpressing $\operatorname{PrP}^{\mathrm{C}}$ grafted in the middle of a Prnp ${ }^{o / o}$ brain might, once infected, serve as a continuous source of $\mathrm{PrP}^{\mathrm{Sc}}$. At this point I had some luck: Sebastian Brandner had started as an intern in neuropathology and did not feel sufficiently challenged with the clinical tasks Paul Kleihues had assigned to him. Sebastian volunteered to devote his spare time to the grafting experiment detailed above, and this was the beginning of a collaboration which has evolved over the last six years. Predictably, prioninfected neurografts derived from PrP-overexpressing transgenic donors, designated tga20 (Fischer et al., 1996), and infected with prions underwent severe degeneration (Figure 2), yet PrP-deficient host mice did not develop clinical symptoms of disease, and brain tissue surrounding the grafts was histologically unaffected despite significant leaks of PrPSc from the graft (Aguzzi et al., 1996; Brandner et al., 1996a). Therefore, expression of $\mathrm{PrPC}^{\mathrm{C}}$ is important not only for replication of the pathological agent, but also for initiation of pathogenesis: $\mathrm{PrP}^{\mathrm{C}}$-deficient neurons failed to succumb to scrapie despite chronic exposure to the agent and to $\mathrm{PrP}^{\mathrm{Sc}}$. These two terms, given the current state of knowledge, do not necessarily indicate the same physical entity (Aguzzi and Weissmann, 1997). The apparent lack of clinical symptoms in mice harboring a scrapiesick graft allowed us to determine what would happen if the disease was allowed to progress for a longer period than the usual life span of mice. Under such circumstances, 


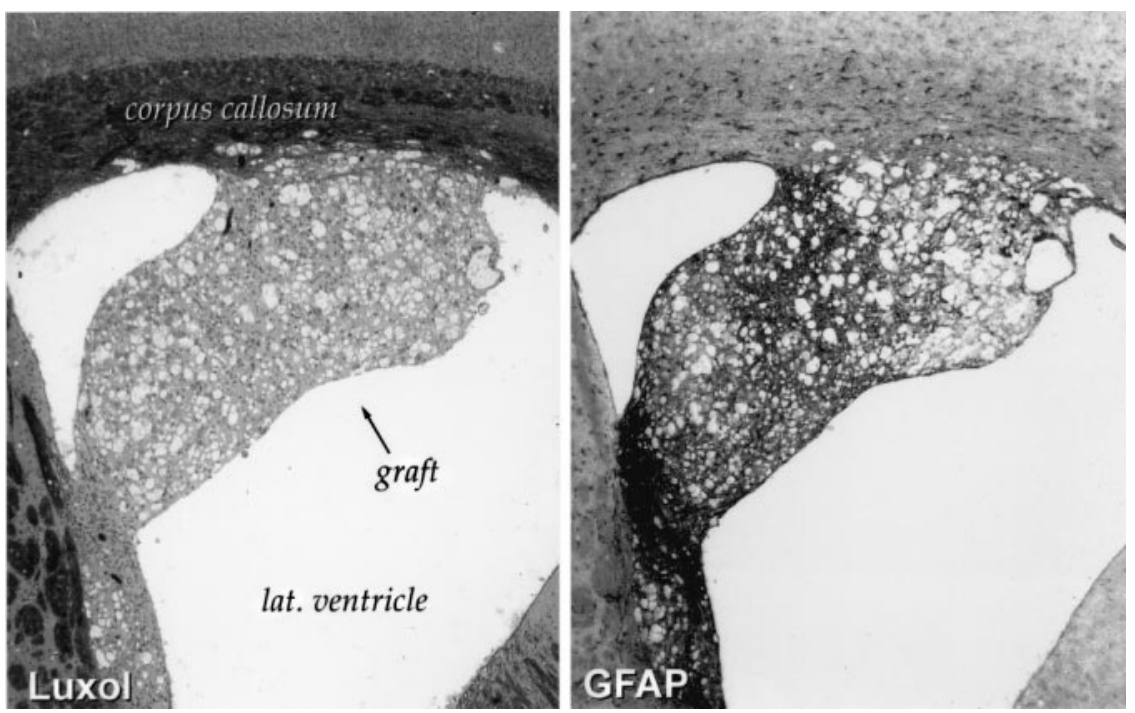

Fig. 2. Histopathology characteristic of scrapie in grafts infected with RML prions. Two hundred and sixty days after inoculation, the graft, which is expressing high levels of $\mathrm{PrP}^{\mathrm{C}}$, has undergone spongiform degeneration. While there is some mild gliosis in the Prnp ${ }^{-/-}$tissue surrounding the graft (most likely due to the mass-shifting effect of the graft, and often seen also in mock-inoculated animals), note that degeneration is strictly confined to the PrP ${ }^{\mathrm{C}}$-expressing tissue. Left, Luxol (white matter stain); right, immunostain for GFAP (a marker of activated astrocytes).

we found neurons to be virtually wiped out while other cell types turned out to be essentially resistant to the disease (Brandner et al., 1998).

In March 1996, the Edinburgh neurology group of Robert Will described the occurrence of a new variant of Creutzfeldt-Jakob disease (nvCJD) which occurred exclusively in very young individuals (Will et al., 1996), and which much circumstantial evidence is incriminating as being caused by the infection of humans with the agent of bovine spongiform encephalopathy (BSE) (Aguzzi, 1996; Aguzzi and Weissmann, 1996; Weissmann and Aguzzi, 1997). The impact of the BSE crisis on the prion research community was already becoming enormous, and was precipitated by this dramatic announcement. From its status of a 'non-existent' disease (as one neurologist in Zurich recently described it), Creutzfeldt-Jakob disease had become a household word literally overnight. It became compelling to wonder whether the research we were doing might bear any practical relevance to the question of whether and how the BSE agent can get into the brain of humans. After all, intracerebral inoculation with prions, though convenient for eliciting spongiform encephalopathy in experimental animals with high efficiency and with minimal latency, is not really the most common method of infection in real life. How do prions, when entering the body through extracerebral sites, manage to reach the central nervous system, which is the only place in the body where they are capable of wreaking havoc? Within the framework of the protein-only hypothesis, at least in its most simplified incarnation, it might be appealing to speculate that single molecules of the scrapie agent might just randomly diffuse through the body, and with some bad luck (from the viewpoint of the patient) hit a nerve cell and start the chain reaction which ultimately leads to spongiform encephalopathy.

One argument, however, deposes strongly against this hypothesis: the latency period from inoculation into the peritoneal cavity to onset of clinical symptoms and to death of experimental animals, is extremely precise.
Although such latency typically extends for 200-250 days, depending on the prion and mouse strains used, its standard deviation when inoculating a defined number of infectious units of scrapie infectivity into the peritoneum of mice is typically in the range of a few percent. Such a precise process bears resemblance to the functioning of Swiss clockwork, and one is reluctant to believe that it is due to a random diffusion event. Besides which, a neuropathologist's clinical experience teaches that most neurotropic viruses have evolved extremely sophisticated mechanisms of invading the brain once inoculated into distant sites. Think of herpes viruses or of rabies virus, both of which exploit retrograde axonal transport and have been conveniently used as tracers to identify networks of neuronal connectivity.

In the case of scrapie prions, a considerable body of older evidence indicated that the peripheral nervous system plays an important role in prion neuroinvasion. In the 1970s, the scientists at the Neuropathogenesis Unit of Edinburgh demonstrated that neural projections, both in the central and in the peripheral nervous system, were pivotal to prion spread; when injected into the footpad or the peritoneal cavity, prions were shown to replicate first in those segments of the spinal cord where the corresponding spinal nerves projected. Intraocular injection led to targeting of the contralateral colliculus superior as expected by the neuroanatomy of the retinotectal projection pathway (Fraser, 1982). The other relevant player in neuroinvasion, which had been identified already when we started our work, was the immune system. Elegant studies by Tetsuyuki Kitamoto (Kitamoto et al., 1991) and others (O’Rourke et al., 1994; Lasmezas et al., 1996) had shown that the lack of an intact immune system would prevent neuroinvasion of prions administered to the peritoneal cavity of mice.

If prions utilize these organ systems to spread throughout the body, which molecules are necessary for this process? Once identified, such molecules could be used to interfere with the spread of prions. A straightforward assumption 
was that $\operatorname{PrP}^{\mathrm{C}}$ itself might represent a crucial element. PrP is not only expressed in the central nervous system but in many other cells of the body, most notably lymphocytes. But how to detect spread of infectivity to the nervous system if one uses PrP-deficient mice? Such mice are, as repeatedly shown by several groups (Büeler et al., 1993; Manson et al., 1994; Sakaguchi et al., 1995), totally resistant to scrapie and cannot replicate the agent. We resorted to introducing a neural graft, which in this case would act as an indicator of neuroinvasion. If the graft developed histopathologically recognizable disease, and accumulated $\mathrm{PrP}^{\mathrm{Sc}}$ and infectivity, this would indicate that neuroinvasion had taken place. It turned out that peripheral inoculation at all the sites we tried never sufficed to achieve neuroinvasion in this system. This was true for the eye, the peritoneal cavity and the footpad.

At first blush, these results would seem to indicate that the absence of normal prion protein totally prevents neuroinvasion in addition to preventing replication of the agent and neurotoxicity. However, the initial enthusiasm we had developed for this theory became somewhat dampened when Charles Weissmann critically reviewed the data and suggested that Prnp knockout mice, which have never seen normal prion protein before in their life, might develop a humoral immune response against PrP when grafted with neuroectodermal tissue heavily overexpressing this protein. Upon his suggestion we looked for evidence of such an immune response, and to our consternation we promptly found it: Western blots of recombinant and mammalian PrP probed with serum of grafted PrP-deficient mice indicated high titers of antiPrP antibodies (Brandner et al., 1996b).

Therefore, it was not clear whether the spread of prion infectivity was prevented by the presence of antibodies or by the absence of PrP. Thanks to the helpfulness of Andreas Sailer, Alex Raeber and Charles Weissmann, we could use a line of mice called $t g 33$, which they had developed for other purposes and which expresses high levels of PrP in T-lymphocytes. Presumably due to clonal deletion during thymic development, these mice are incapable of mounting an anti-PrP immune response. When we repeated the experiment with $\operatorname{tg} 33$ mice, we found that intraocular (but not intraperitoneal) inoculation still failed to produce disease in the graft. Therefore, at least for the intraocular route, we concluded that absence of PrP effectively prevents the spread of prions (Brandner et al., 1996b). This does not necessarily mean, however, that anti-PrP antibodies will not prevent prion spread, and Christine Musahl and Ivan Hegyi are pursuing this question using transgenic and immunological techniques.

Given the large amount of literature supporting an important role of the immune system in prion spread, we embarked on a bone marrow grafting enterprise using PrP-expressing mice (wild-type or tga20 transgenic) as donors, and Prnp knockout mice with a PrP-expressing graft in their brain as recipients. Thomas Blättler, a student in my laboratory who in the meantime has gone on to become a neurologist, has been performing these studies with significant help from the crew of Rolf Zinkernagel. Thomas found that this manipulation sufficed to restore accumulation of prions in spleen, and we were certainly predicting that it would suffice to restore neuroinvasion. Instead, we were almost shocked to learn that the contrary was in fact the case (Figure 3). We detected scrapie histopathology in only one of 28 grafts of bone marrowreconstituted mice. This led us to propose a model in which the immune system is important for moving prions from the site of injection to lymphatic organs; however, PrP expression in peripheral nerves might be crucial for actual neuroinvasion (Blättler et al., 1997).

Unfortunately, the latter hypothesis was to prove rather resilient to all attempts at positive experimental verification. Ideally, one would wish to reconstitute expression of $\operatorname{PrP}^{\mathrm{C}}$ on peripheral nerves selectively and show this manipulation to be sufficient for restoration of neuroinvasion. We are attempting to achieve this with the help of PrP-transducing adenoviral vectors which were generated by Eckhard Flechsig and Charles Weissmann. Conversely, Weissmann and Bea Navarro are attempting a similar experiment by the transgenic route using promoters specific to the peripheral nervous system.

Since manipulation of the immune system seemed easier to accomplish, we sought to identify specific cell types in lymphoid organs which might be relevant to neuroinvasion. At this point, I was extremely lucky to elicit in Rolf Zinkernagel some interest for this project. Zinkernagel was (and probably still is) not a fervent supporter of the protein-only hypothesis: he was intrigued by the possibility that prion diseases may be intimately connected to dysfunctions of the immune system although he never yielded to pleas to explain such thoughts in more detail. Rolf Zinkernagel and Hans Hengartner, who are conveniently located one floor above us at the Institute of Experimental Immunology in Zurich, had assembled a collection of various immunodeficient mice gathered from laboratories all over the world with specific defects of the immune system, and made them available to us for inoculation into brain and peripheral sites.

Michael Klein, who had joined my laboratory after a postdoctoral period in experimental neuropathology in Munich, took on the task of assessing the sensitivity to scrapie of all these mutant strains. Contrary to Zinkernagel's guess (which he underlined by betting some champagne with us on its correctness), all mice suffering from immune deficiencies developed scrapie within the normal latency when inoculated intracerebrally. After intraperitoneal inoculation, however, all mice that lacked terminally differentiated B-lymphocytes did not develop disease (Table II), suggesting a crucial role for these cells in the transport of prions (Klein et al., 1997). Even $\mu \mathrm{MT}$ mice carrying a targeted disruption of the transmembrane domain of the immunoglobulin $\mu$ chain, whose only defect consists of lack of terminal maturation of B-cells (Kitamura et al., 1991), were protected (Table II). Rico Frigg and Michael Klein are now investigating whether the presence of PrP on the surface of B-lymphocytes is important for neuroinvasion: preliminary results indicate that we may be in for some surprises with this particular experiment.

\section{Homework for the next few years}

Does any of the above bear any relevance to the BSE crisis? Undoubtedly, it would be highly desirable to develop some sort of post-exposure prophylaxis for prion diseases, especially when one considers that a large fraction of the population may have been exposed to the 


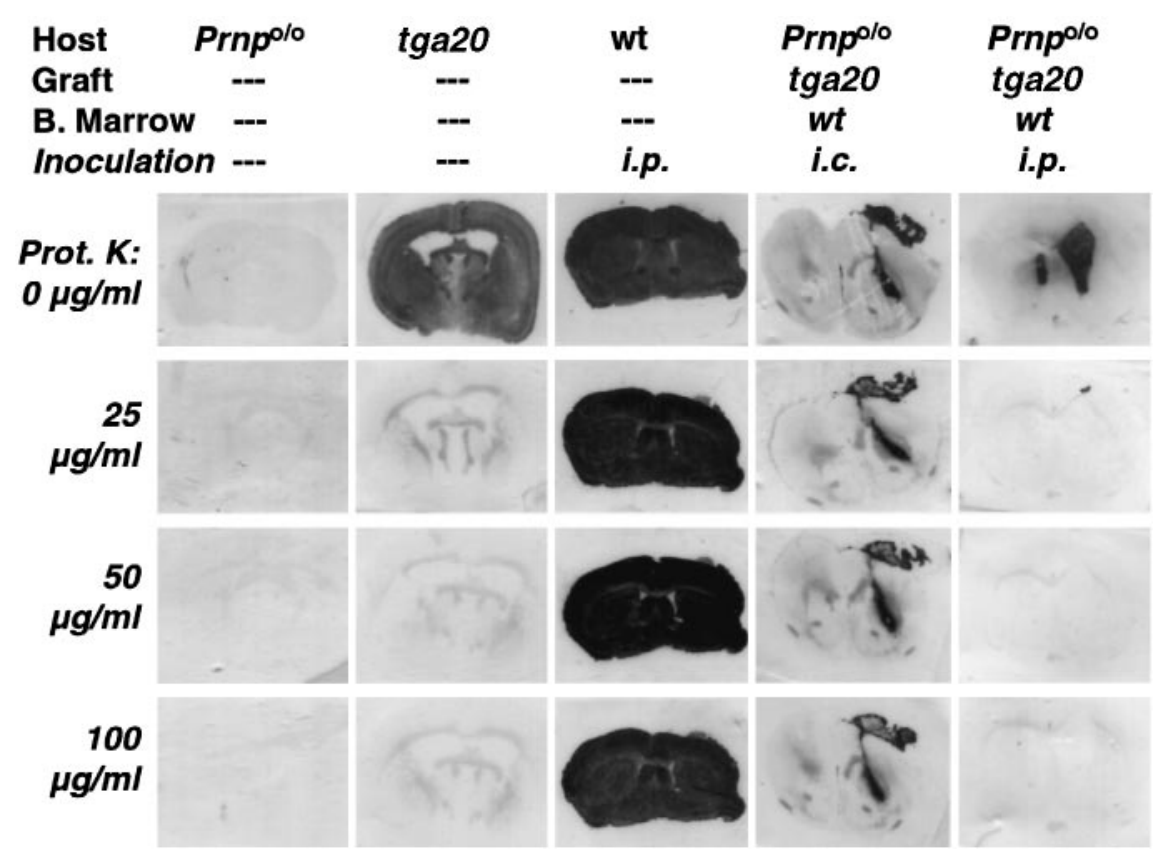

Fig. 3. Accumulation of $\mathrm{PrP}^{\mathrm{Sc}}$ in brain grafts. Histoblots showing immunoreactive $\operatorname{PrP}$ in brain sections natively (first row) and after digestion with increasing levels of proteinase $\mathrm{K}$ (second to fourth row). Prnp ${ }^{o / o}$ mice (first column) show no immunoreactivity, while mock-inoculated tga20 mice (which overexpress $\mathrm{PrP}^{\mathrm{C}}$ ) show proteinase K-sensitive $\operatorname{PrP}^{\mathrm{C}}$ (second column), but no proteinase K-resistant PrP ${ }^{\mathrm{Sc}}$. Terminally sick scrapie-infected wild-type mice contain large amounts of both $\mathrm{PrP}^{\mathrm{C}}$ and $\mathrm{PrP}^{\mathrm{Sc}}$ (third column). Prnp $p^{o / o}$ whose bone marrow has been reconstituted with wild-type FLCs accumulate $\mathrm{PrP}^{\mathrm{Sc}}$ in their $\mathrm{PrP}^{\mathrm{C}}$-overexpressing grafts after i.c. (fourth column) but not after i.p. prion administration (fifth column).

Table II. Results of scrapie inoculation experiments into mice displaying various immune defects

\begin{tabular}{|c|c|c|c|c|c|c|}
\hline \multirow[t]{2}{*}{ Defect } & \multirow[t]{2}{*}{ Genotype } & \multirow[t]{2}{*}{ Strain } & \multicolumn{2}{|c|}{ Intracerebral inoculation } & \multicolumn{2}{|c|}{ Intraperitoneal inoculation } \\
\hline & & & Scrapie & $\begin{array}{l}\text { Incubation } \\
(\mathrm{d} \pm \mathrm{SD})\end{array}$ & Scrapie & $\begin{array}{l}\text { Incubation } \\
(\mathrm{d} \pm \mathrm{SD})\end{array}$ \\
\hline $\mathrm{T}$ cells & 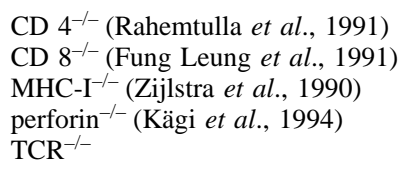 & $\begin{array}{l}\text { C57BL/6 } \\
\text { C57BL/6 } \\
\text { C57BL/6 } \\
\text { C57BL/6 } \\
\text { C57BL/6 }\end{array}$ & $\begin{array}{l}7 / 7 \\
6 / 6 \\
8 / 8 \\
3 / 4 * \\
6 / 6\end{array}$ & $\begin{array}{l}159 \pm 11 \\
157 \pm 15 \\
162 \pm 11 \\
171 \pm 2 \\
148 \pm 7\end{array}$ & $\begin{array}{l}8 / 8 \\
6 / 6 \\
7 / 7 \\
4 / 4 \\
9 / 9\end{array}$ & $\begin{array}{l}191 \pm 1 \\
202 \pm 5 \\
211 \pm 6 \\
204 \pm 2 \\
191 \pm 13\end{array}$ \\
\hline $\mathrm{B}+\mathrm{T}$ cells & $\begin{array}{l}\text { SCID (leaky) } \\
\text { SCID } \\
\text { RAG-2-- (Shinkai et al., 1992) } \\
\text { RAG-1 }{ }^{-/-} \text {(Mombaerts et al., 1992) }\end{array}$ & $\begin{array}{l}\text { C57BL/6 } \\
\text { C.B-17 } \\
\text { C57BL/6 } \\
\text { C57BL/6 }\end{array}$ & $\begin{array}{l}7 / 8 * \\
4 / 4 \\
7 / 7 \\
3 / 3\end{array}$ & $\begin{array}{l}160 \pm 10 \\
152 \pm 1 \\
167 \pm 2 \\
175 \pm 2\end{array}$ & $\begin{array}{l}6 / 8 \\
0 / 8 \\
0 / 7 \\
0 / 5\end{array}$ & $\begin{array}{l}226 \pm 15 \\
\text { healthy }(>350) \\
\text { healthy }(>504) \\
\text { healthy }(>270)\end{array}$ \\
\hline $\mathrm{B}+\mathrm{T}$ cells + interferons & $\mathrm{AGR}^{-/}$(M.Suter, unpublished) & 129 & $6 / 6$ & $184 \pm 9$ & $0 / 7$ & healthy $(>470)$ \\
\hline $\begin{array}{l}\text { B cells, all immunoglobulins } \\
\text { IgG, skewed IgM repertoire }\end{array}$ & $\begin{array}{l}\mu \mathrm{MT} \text { (Kitamura et al., 1991) } \\
\text { t11 } \mu \mathrm{MT} \text { (Klein et al., 1997) }\end{array}$ & $\begin{array}{l}\text { C57BL/6 } \\
\text { C57BL/6 }\end{array}$ & $\begin{array}{l}8 / 8 \\
5 / 5\end{array}$ & $\begin{array}{l}181 \pm 6 \\
170 \pm 2\end{array}$ & $\begin{array}{l}0 / 8 \\
4 / 4\end{array}$ & $\begin{array}{l}\text { healthy }(>612) \\
223 \pm 2\end{array}$ \\
\hline FDC & $\begin{array}{l}\text { TNFR1 }{ }^{-1-} \text { (Rothe } \text { et al., 1993) } \\
\text { wild-type } \\
\text { wild-type }\end{array}$ & $\begin{array}{l}129 \\
129 \\
\mathrm{C} 57 \mathrm{~B} 1 / 6\end{array}$ & $\begin{array}{l}7 / 7 \\
4 / 4 \\
4 / 4\end{array}$ & $\begin{array}{l}165 \pm 3 \\
167 \pm 9 \\
166 \pm 2\end{array}$ & $\begin{array}{l}9 / 9 \\
4 / 4 \\
4 / 4\end{array}$ & $\begin{array}{l}216 \pm 10 \\
193 \pm 3 \\
206 \pm 2\end{array}$ \\
\hline
\end{tabular}

Mice with various immune defects were inoculated with RML scrapie prions intracerebrally or intraperitoneally. While all intracerebrally inoculated mice developed scrapie with a latency similar to that of wild-type mice, intraperitoneal inoculation resulted in scrapie in T-cell deficient mice, but not in mice displaying defects in the maturation of B-lymphocytes. SCID mice bred on the C57B1/6 genetic background developed scrapie; however, these mice are leaky (Bosma and Carroll, 1991; Nonoyama et al., 1993) and tend to contain a residual population of lymphocytes. FDC; follicular dendritic cells.

BSE agent in Great Britain and continental Europe, but this will only be possible if prionotropic molecules and cells can be identified, which may offer a handle on interfering with the spread of prions. It is unclear how long prions persist in the body when their replication is prevented (Aguzzi and Weissmann, 1998), but under certain circumstances prion clearance may be rather fast. Yet, total immune depletion does not represent a feasible practical solution for humans, except perhaps after massive exposure at a known and well-defined time point (Aguzzi and Collinge, 1997). Even selectively killing B-lymphocytes may be problematic. I deem it realistic to hope that in the next few years the refinement of our understanding of the mechanisms of prion neuroinvasion will lead to the development of effective strategies of post-exposure prophylaxis, and perhaps even of therapy. 
Finally, I do not want to leave unmentioned the unusual events which have kept me busy in the first half of 1998. Swiss scientists have recently escaped a terrible threat. The population had been asked to vote on an amendment of the Swiss Constitution that would ban all genetic manipulation of animals, including worms and flies. Needless to say, this would have throttled Swiss biomedical research. At the beginning of the year, the polls were thoroughly negative and provoked a lot of gloom within the Swiss research community. The neurografting experiments described above seemed to be just the things that would enrage the vociferous coalition of animal rights campaigners and 'gene protectionists' who supported the initiative. Consequently, my colleagues and I undertook to go public and explain, in podium discussions, interviews on radio, on TV and in the newspapers, what we were doing and why. These activities demanded a large share of our time and certainly affected scientific productivity but, as a result, reason eventually prevailed and the illconceived 'gene protection' initiative was defeated by a 2:1 ratio. The lesson I personally learned from these events is that education of the population with respect to the methods and the goals of science is just as much a part of our job as experimental work. Take both tasks seriously, and we will retain the support of the public.

\section{Acknowledgements}

I am profoundly grateful to those scientists who have taught me the craftsmanship of neuropathology and of molecular biology, most notably Paul Kleihues, Erwin Wagner, Charles Weissmann and Rolf Zinkernagel. Many thanks also to Klaus Rajewsky for making the B-cell-deficient $\mu \mathrm{MT}$ mice available to us (see Table II); they are proving invaluable in the study of prion neuroinvasion. The current crew at the Institute of Neuropathology in Zurich consists of extremely motivated, intelligent and hard-working colleagues from many different countries: it is an immense pleasure to devise experiments and discuss results with them. Special thanks also to Norbert Wey for help with artwork over several years, and to Beatrice Züger and Regula Chase for guarding some system in the chaotic life of the Institute of Neuropathology and its director. Also, I am profoundly grateful to Monika Landert for bearing with me through difficult times. The work described in these pages was supported by numerous funding agencies, most notably the Kanton of Zurich, the Swiss National Science Foundation, the Bundesämter für Gesundheit, Veterinärwesen und Erziehung, the Migros Foundation, and the companies Abbott and Immuno.

\section{References}

Aguzzi,A. (1993) The foamy virus family: molecular biology, epidemiology and neuropathology. Biochim. Biophys. Acta, 1155, $1-24$.

Aguzzi,A. (1996) Between cows and monkeys. Nature, 381, 734.

Aguzzi,A. and Weissmann,C. (1996) Spongiform encephalopathies: a suspicious signature. Nature, 383, 666-667.

Aguzzi,A. and Collinge,J. (1997) Post-exposure prophylaxis after accidental prion inoculation. Lancet, 350, 1519-1520.

Aguzzi,A. and Weissmann,C. (1997) Prion research: the next frontiers. Nature, 389, 795-798.

Aguzzi,A. and Weissmann,C. (1998) Spongiform encephalopathies. The prion's perplexing persistence. Nature, 392, 763-764.

Aguzzi,A., Wagner,E.F., Williams,R.L. and Courtneidge,S.A. (1990) Sympathetic hyperplasia and neuroblastomas in transgenic mice expressing polyoma middle T antigen. New Biol., 2, 533-543.

Aguzzi,A., Kleihues,P., Heckl,K. and Wiestler,O.D. (1991) Cell typespecific tumor induction in neural transplants by retrovirus-mediated oncogene transfer. Oncogene, 6, 113-118.

guzzi,A., Bothe,K., Anhauser,I., Horak,I., Rethwilm,A. and Wagner,E.F. (1992a) Expression of human foamy virus is differentially regulated during development in transgenic mice. New Biol., 4, 225-237.
Aguzzi,A., Bothe,K., Wagner,E.F., Rethwilm,A. and Horak,I. (1992b) Human foamy virus: an underestimated neuropathogen? Brain Pathol., 2, 61-69.

Aguzzi,A., Wagner,E.F., Netzer,K.O., Bothe,K., Anhauser,I. and Rethwilm,A. (1993) Human foamy virus proteins accumulate in neurons and induce multinucleated giant cells in the brain of transgenic mice. Am. J. Pathol., 142, 1061-1071.

Aguzzi,A., Brandner,S., Marino,S. and Steinbach,J.P. (1996) Transgenic and knockout mice in the study of neurodegenerative diseases. $J$. Mol. Med., 74, 111-126.

Basler,K., Oesch,B., Scott,M., Westaway,D., Walchli,M., Groth,D.F., McKinley,M.P., Prusiner,S.B. and Weissmann,C. (1986) Scrapie and cellular PrP isoforms are encoded by the same chromosomal gene. Cell, 46, 417-428.

Bieniasz,P.D., Erlwein,O., Aguzzi,A., Rethwilm,A. and McClure,M.O. (1997) Gene transfer using replication-defective human foamy virus vectors. Virology, 235, 65-72.

Blättler,T., Brandner,S., Raeber,A.J., Klein,M.A., Voigtländer,T., Weissmann,C. and Aguzzi,A. (1997) PrP-expressing tissue required for transfer of scrapie infectivity from spleen to brain. Nature, 389, 69-73.

Bosma,M.J. and Carroll,A.M. (1991) The SCID mouse mutant: definition, characterization and potential uses. Annu. Rev. Immunol., 9, 323-350.

Bothe,K., Aguzzi,A., Lassmann,H., Rethwilm,A. and Horak,I. (1991) Progressive encephalopathy and myopathy in transgenic mice expressing human foamy virus genes. Science, 253, 555-557.

Boulter,C.A., Aguzzi,A., Williams,R.L., Wagner,E.F., Evans,M.J. and Beddington,R. (1991) Expression of $\mathrm{v}$-src induces aberrant development and twinning in chimeric mice. Development, 111, 357-366.

Brandner,S., Isenmann,S., Raeber,A., Fischer,M., Sailer,A., Kobayashi,Y., Marino,S., Weissmann,C. and Aguzzi,A. (1996a) Normal host prion protein necessary for scrapie-induced neurotoxicity. Nature, 379, 339-343.

Brandner,S., Raeber,A., Sailer,A., Blaettler,T., Fischer,M., Weissmann,C. and Aguzzi,A. (1996b) Normal host prion protein (PrPC) required for scrapie spread within the central nervous system. Proc. Natl Acad. Sci. USA, 93, 13148-13151.

Brandner,S., Isenmann,S., Kuhne,G. and Aguzzi,A. (1998) Identification of the end stage of scrapie using infected neural grafts. Brain Pathol., 8, 19-27.

Büeler,H.R., Aguzzi,A., Sailer,A., Greiner,R.A., Autenried,P., Aguet,M. and Weissmann,C. (1993) Mice devoid of PrP are resistant to scrapie. Cell, 73, 1339-1347.

Büeler,H.R., Fischer,M., Lang,Y., Bluethmann,H., Lipp,H.P., DeArmond,S.J., Prusiner,S.B., Aguet,M. and Weissmann,C. (1992) Normal development and behaviour of mice lacking the neuronal cellsurface PrP protein. Nature, 356, 577-582.

Cooper,J.A., Gould,K.L., Cartwright,C.A. and Hunter,T. (1986) Tyr527 is phosphorylated in pp60c-src: implications for regulation. Science, 231, 1431-1434.

Courtneidge,S.A. and Smith,A.E. (1983) Polyoma virus transforming protein associates with the product of the c-src cellular gene. Nature, 303, 435-439.

Fischer,M., Rülicke,T., Raeber,A., Sailer,A., Moser,M., Oesch,B., Brandner,S., Aguzzi,A. and Weissmann,C. (1996) Prion protein (PrP) with amino-proximal deletions restoring susceptibility of PrP knockout mice to scrapie. EMBO J., 15, 1255-1264.

Fraser,H. (1982) Neuronal spread of scrapie agent and targeting of lesions within the retino-tectal pathway. Nature, 295, 149-150.

Fung Leung,W.P., Schilham,M.W., Rahemtulla,A., Kundig,T.M., Vollenweider,M., Potter,J., van Ewijk,W. and Mak,T.W. (1991) CD8 is needed for development of cytotoxic $\mathrm{T}$ cells but not helper $\mathrm{T}$ cells. Cell, 65, 443-449.

Giacomini,P., Aguzzi,A., Pestka,S., Fisher,P.B. and Ferrone,S. (1984) Modulation by recombinant DNA leukocyte $(\alpha)$ and fibroblast $(\beta)$ interferons of the expression and shedding of HLA- and tumorassociated antigens by human melanoma cells. J. Immunol., 133, 1649-1655.

Giacomini,P., Aguzzi,A., Tecce,R., Fisher,P.B. and Ferrone,S. (1985a) A third polypeptide associated with heavy and light chain subunits of class I HLA antigens in immune interferon-treated human melanoma cells. Eur. J. Immunol., 15, 946-951.

Giacomini,P., Imberti,L., Aguzzi,A., Fisher,P.B., Trinchieri,G. and Ferrone,S. (1985b) Immunochemical analysis of the modulation of human melanoma-associated antigens by DNA recombinant immune interferon. J. Immunol., 135, 2887-2894. 
Giacomini,P., Aguzzi,A. and Ferrone,S. (1986) Differential susceptibility to modulation by recombinant immune interferon of HLA-DR and -DQ antigens synthesized by melanoma COLO 38 cells. Hybridoma, 5, 277-288.

Gray,P.W. et al. (1982) Expression of human immune interferon cDNA in E.coli and monkey cells. Nature, 295, 503-508.

Hilberg,F., Aguzzi,A., Howells,N. and Wagner,E.F. (1993) c-jun is essential for normal mouse development and hepatogenesis (published erratum appears in Nature (1993), 366, 368]. Nature, 365, 179-181.

Isaacs,A. and Lindenmann,J. (1957) Virus interference. 1. The interferon. Proc. R. Soc. Lond., 147, 258-273.

Isenmann,S., Brandner,S., Kuhne,G., Boner,J. and Aguzzi,A. (1996a) Comparative in vivo and pathological analysis of the blood-brain barrier in mouse telencephalic transplants. Neuropathol. Appl. Neurobiol., 22, $118-128$.

Isenmann,S., Brandner,S., Sure,U. and Aguzzi,A. (1996b) Telencephalic transplants in mice: characterization of growth and differentiation patterns. Neuropathol. Appl. Neurobiol., 21, 108-117.

Isenmann,S., Molthagen,M., Brandner,S., Bartsch,U., Kühne,G., Magyar,J.P., Sure,U., Schachner,M. and Aguzzi,A. (1995) The AMOG AMOG/B2 subunit of $\mathrm{Na}, \mathrm{K}-\mathrm{ATPase}$ is not necessary for long term survival of telencephalic grafts. Glia, 15, 377-388.

Jonkers,J. and Berns,A. (1996) Retroviral insertional mutagenesis as a strategy to identify cancer genes. Biochim. Biophys. Acta, 1287, 29-57.

Kägi,D., Ledermann,B., Bürki,K., Seiler,P., Odermatt,B., Olsen,K.J., Podack,E.R., Zinkernagel,R.M. and Hengartner,H. (1994) Cytotoxicity mediated by $\mathrm{T}$ cells and natural killer cells is greatly impaired in perforin-deficient mice. Nature, 369, 31-37.

Kiefer,F., Anhauser,I., Soriano,P., Aguzzi,A., Courtneidge,S.A. and Wagner,E.F. (1994) Endothelial cell transformation by polyomavirus middle $\mathrm{T}$ antigen in mice lacking Src-related kinases. Curr. Biol., 4, $100-109$.

Kitamoto,T., Muramoto,T., Mohri,S., Dohura,K. and Tateishi,J. (1991) Abnormal isoform of prion protein accumulates in follicular dendritic cells in mice with Creutzfeldt-Jakob disease. J. Virol., 65, 6292-6295.

Kitamura,D., Roes,J., Kuhn,R. and Rajewsky,K. (1991) A B celldeficient mouse by targeted disruption of the membrane exon of the immunoglobulin $\mu$ chain gene. Nature, 350, 423-426.

Klein,M.A. et al. (1997) A crucial role for B cells in neuroinvasive scrapie. Nature, 390, 687-690.

Lampe,J., Marino,S., Rethwilm,A. and Aguzzi,A. (1998) Degeneration of the cerebellar granule cell layer in transgenic mice expressing genes of human foamy virus. Neuropathol. Appl. Neurobiol., 24, 36-43.

Lasmezas,C.I., Cesbron,J.Y., Deslys,J.P., Demaimay,R., Adjou,K.T., Rioux,R., Lemaire,C., Locht,C. and Dormont,D. (1996) Immune system-dependent and -independent replication of the scrapie agent. J. Virol., 70, 1292-1295.

Magyar,J.P., Bartsch,U., Wang,Z.Q., Howells,N., Aguzzi,A., Wagner,E.F. and Schachner,M. (1994) Degeneration of neural cells in the central nervous system of mice deficient in the gene for the adhesion molecule on Glia, the $\beta 2$ subunit of murine Na,K-ATPase. J. Cell Biol., 127, 835-845.

Manson,J.C., Clarke,A.R., McBride,P.A., McConnell,I. and Hope,J. (1994) PrP gene dosage determines the timing but not the final intensity or distribution of lesions in scrapie pathology. Neurodegeneration, $\mathbf{3}$, $331-340$.

Marino,S., Kretschmer,C., Brandner,S., Cavard,C., Zider,A., Briand,P., Isenmann,S., Wagner,E.F. and Aguzzi,A. (1995) Activation of HIV transcription by human foamy virus in transgenic mice. Lab. Invest., 73, 103-110.

Mombaerts,P., Iacomini,J., Johnson,R.S., Herrup,K., Tonegawa,S. and Papaioannou,V.E. (1992) RAG-1-deficient mice have no mature B and T lymphocytes. Cell, 68, 869-877.

Nagata,S., Taira,H., Hall,A., Johnsrud,L., Streuli,M., Ecsodi,J., Boll,W., Cantell,K. and Weissmann,C. (1980) Synthesis in E.coli of a polypeptide with human leukocyte interferon activity. Nature, 284, 316-320.

Natali,P.G., Aguzzi,A., Veglia,F., Imai,K., Burlage,R.S., Giacomini,P. and Ferrone,S. (1983) The impact of monoclonal antibodies on the study of human malignant melanoma. J. Cutan. Pathol., 10, 514-528.

Netzer,K.O., Schliephake,A., Maurer,B., Watanabe,R., Aguzzi,A. and Rethwilm,A. (1993) Identification of pol-related gene products of human foamy virus. Virology, 192, 336-338.

Nonoyama,S., Smith,F.O., Bernstein,I.D. and Ochs,H.D. (1993) Straindependent leakiness of mice with severe combined immune deficiency. J. Immunol., 150, 3817-3824.
Oesch,B. et al. (1985) A cellular gene encodes scrapie PrP 27-30 protein. Cell, 40, 735-46.

Oesch,B., Groth,D.F., Prusiner,S.B. and Weissmann,C. (1988) Search for a scrapie-specific nucleic acid: a progress report. Ciba. Found. Symp., 135, 209-223.

O'Rourke,K.I., $\quad$ Huff,T.P., Leathers,C.W., Robinson,M.M. and Gorham,J.R. (1994) SCID mouse spleen does not support scrapie agent replication. J. Gen. Virol., 75, 1511-1514.

Rahemtulla,A. et al. (1991) Normal development and function of CD8+ cells but markedly decreased helper cell activity in mice lacking CD4 Nature, 353, 180-184.

Rothe,J. et al. (1993) Mice lacking the tumour necrosis factor receptor 1 are resistant to TNF-mediated toxicity but highly susceptible to infection by Listeria monocytogenes. Nature, 364, 798-802.

Sailer,A., Büeler,H., Fischer,M., Aguzzi,A. and Weissmann,C. (1994) No propagation of prions in mice devoid of PrP. Cell, 77, 967-968.

Sakaguchi,S. et al. (1995) Accumulation of proteinase K-resistant prion protein $(\mathrm{PrP})$ is restricted by the expression level of normal PrP in mice inoculated with a mouse-adapted strain of the Creutzfeldt-Jakob disease agent. J. Virol., 69, 7586-7592.

Schmidt,M., Niewiesk,S., Heeney,J., Aguzzi,A. and Rethwilm,A. (1997) Mouse model to study the replication of primate foamy viruses. $J$. Gen. Virol., 78, 1929-1933.

Shinkai,Y. et al. (1992) RAG-2-deficient mice lack mature lymphocytes owing to inability to initiate V (D)J rearrangement. Cell, 68, 855-867.

Thomas,J.E., Aguzzi,A., Soriano,P., Wagner,E.F. and Brugge,J.S. (1993) Induction of tumor formation and cell transformation by polyoma middle $\mathrm{T}$ antigen in the absence of Src. Oncogene, 8, 2521-2529.

Thomas,J.E., Soriano,P. and Brugge,J.S. (1991) Phosphorylation of c-Src on tyrosine 527 by another protein tyrosine kinase. Science, 254, 568-571.

Tschopp,R.R., Brandner,S., Marino,S., Bothe,K., Horak,I., Rethwilm,A. and Aguzzi,A. (1996) Analysis of the determinants of neurotropism and neurotoxicity of HFV in transgenic mice. Virology, 216, 338-346.

Wagner,E.F. (1990) EMBO medal review. On transferring genes into stem cells and mice. EMBO J., 9, 3024-3032.

Wagner,E.F. and Aguzzi,A. (1992) Exploring the pathogenic potential of polyoma middle T, c-fos and Human Foamy Virus in transgenic mice. In Theuring,F. and Wagner,E.F. (eds). Transgenic Animals as Model Systems for Human Diseases. Springer, Berlin, Germany, pp. 109-198.

Weissenberger,J., Steinbach,J.P., Malin,G., Spada,S., Rulicke,T. and Aguzzi,A. (1997) Development and malignant progression of astrocytomas in GFAP-v-src transgenic mice. Oncogene, 14, 20052013

Weissmann,C. (1989) Prions. Sheep disease in human clothing. Nature, 338, 298-299.

Weissmann,C. (1991a) Spongiform encephalopathies. The prion's progress. Nature, 349, 569-571.

Weissmann,C. (1991b) A 'unified theory' of prion propagation. Nature, 352, 679-683.

Weissmann,C. and Aguzzi,A. (1997) Bovine spongiform encephalopathy and early onset variant Creutzfeldt-Jakob disease. Curr. Opin. Neurobiol., 7, 695-700.

Will,R.G. et al. (1996) A new variant of Creutzfeldt-Jakob disease in the UK. Lancet, 347, 921-925.

Williams,R.L., Risau,W., Zerwes,H.G., Drexler,H., Aguzzi,A. and Wagner,E.F. (1989) Endothelioma cells expressing the polyoma middle $\mathrm{T}$ oncogene induce hemangiomas by host cell recruitment. Cell, 57, 1053-1063.

Zijlstra,M., Bix,M., Simister,N.E., Loring,J.M., Raulet,D.H. and Jaenisch,R. (1990) Beta 2-microglobulin deficient mice lack CD4-8+ cytolytic T cells. Nature, 344, 742-746. 